\title{
Sol-Gel Synthesis, X-Ray Diffraction Studies, and Electric Conductivity of Sodium Europium Silicate
}

\author{
Ekaterina V. Borisova, ${ }^{1}$ Alexey V. Ignatov, ${ }^{1}$ Eugeni I. Get'man, ${ }^{1}$ Stanislav N. Loboda, \\ Lyudmyla I. Ardanova, ${ }^{2}$ Lyudmila V. Pasechnik, ${ }^{1}$ and Vitaly S. Ponurovsky ${ }^{1}$ \\ ${ }^{1}$ Department of Inorganic Chemistry, Donetsk National University, 24 Universitetskaya, Donetsk 83001, Ukraine \\ ${ }^{2}$ Department of Chemistry and Geology, Minnesota State University, Mankato, 241 Ford Hall, Mankato, MN 56001, USA \\ Correspondence should be addressed to Lyudmyla I. Ardanova; lyudmyla.stackpool@mnsu.edu
}

Received 8 October 2012; Revised 11 December 2012; Accepted 25 December 2012

Academic Editor: Michele Benedetti

Copyright (C) 2013 Ekaterina V. Borisova et al. This is an open access article distributed under the Creative Commons Attribution License, which permits unrestricted use, distribution, and reproduction in any medium, provided the original work is properly cited.

Sodium europium silicate, $\mathrm{NaEu}_{9}\left(\mathrm{SiO}_{4}\right)_{6} \mathrm{O}_{2}$, with apatite structure has been obtained and studied using X-ray diffraction and SEM. It has been shown that sodium sublimation does not take place upon synthesis by the sol-gel method. Rietveld refinement has revealed that sodium atoms are ordered and occupy the $4 \mathrm{f}$ position. $\mathrm{O}(4)$ atoms not related to silicate ions are placed at the centers of $\mathrm{Eu}(2)$ triangles. DC and AC electric conductivity and activation energy have been determined for the compound studied.

\section{Introduction}

Compounds with apatite-type structure are widely investigated because they can be used as biomaterials [1], catalysts [2], ionic conductors [3], and luminescent materials [4]. Studies on electrical conductivity of these compounds have been motivated by research in which high ionic conductivity of $\mathrm{La}_{9.33}\left(\mathrm{SiO}_{4}\right)_{6} \mathrm{O}_{2}$ has been previously determined [5]. Subsequently, similar results have been obtained for germanates, which also exhibit high ionic conductivity [6]. Rare earth silicates with apatite structure are of great interest as a new class of oxygen ionic conductors. The characteristics of their structure provide high oxygen conductivity at a medium temperature range, low activation energy of conductivity, stability in reducing media, and a possibility for isomorphous substitution by different elements to modify their transport properties [7]. Lanthanide silicates have been synthesized in a single crystal as well as in polycrystalline form. polycrystalline lanthanide silicates with apatite structure were synthesized by solid phase methods, including mechanochemical synthesis [8] and the sol-gel method [9]. Single crystals were obtained by a hydrothermal method [10]. The compounds of $\mathrm{Ln}_{9.33}\left(\mathrm{SiO}_{4}\right)_{6} \mathrm{O}_{2}, \mathrm{NaLn}_{9}\left(\mathrm{SiO}_{4}\right)_{6} \mathrm{O}_{2}$, and $\mathrm{LiLn}_{9}\left(\mathrm{SiO}_{4}\right)_{6} \mathrm{O}_{2}$ have been obtained by the solid phase method utilizing all of the rare earths. Mixtures containing corresponding oxides and salts have been pressed into pellets with a pressure of $200 \mathrm{~kg} / \mathrm{cm}^{2}$ and sintered at the temperature ranging from 1000 to $1900^{\circ} \mathrm{C}$ for 24 hours. The lattice parameters of the compounds have been obtained [11], but the crystalline structure was not studied in detail. The compounds of $\mathrm{Eu}_{8.18} \mathrm{Na}_{1.08}\left(\mathrm{SiO}_{4}\right)_{6}(\mathrm{OH})_{1.62-2 \mathrm{y}} \mathrm{O}_{\mathrm{y}}$ and $\mathrm{Eu}_{3.96} \mathrm{Gd}_{3.96} \mathrm{Na}_{1.2}\left(\mathrm{SiO}_{4}\right)_{6}(\mathrm{OH})_{1.86-2 \mathrm{y}} \mathrm{O}_{\mathrm{y}}$ have been obtained by hydrothermal synthesis and their crystalline structures have been studied [12]. Indeed, the accuracy of the suggested formulae is not quite clear, considering fractional coefficients and presence of vacancies at the cation sites and in the structural channels. the electrophysical properties of these compounds have not been studied.

\section{Experimental Procedure}

In the current study, $\mathrm{NaEu}_{9}\left(\mathrm{SiO}_{4}\right)_{6} \mathrm{O}_{2}$, as an example of alkali and rare earth element apatite, has been synthesized using the sol-gel method. The crystalline structure and electrophysical properties of this compound have been investigated in detail.

Highly pure $\mathrm{Na}_{2} \mathrm{CO}_{3}$ ( $>99.99 \%$ purity), tetraethoxysilane (TEOS) $\mathrm{Si}\left(\mathrm{OC}_{2} \mathrm{H}_{5}\right)_{4}$ (>98\% purity), and $\mathrm{Eu}_{2} \mathrm{O}_{3}$ (>99.99\% 
TABLE 1: Results of elemental analysis for $\mathrm{NaEu}_{9}\left(\mathrm{SiO}_{4}\right)_{6} \mathrm{O}_{2}$ (\% by weight).

\begin{tabular}{lccccc}
\hline Section \# & $\begin{array}{c}\text { Number of points } \\
\text { (regions) }\end{array}$ & $\mathrm{O}$ & $\mathrm{Na}$ & $\mathrm{Si}$ & $\mathrm{Eu}$ \\
\hline 1 & 7 & 21.18 & 1.14 & 8.67 & 69.01 \\
2 & 12 & 21.43 & 1.12 & 8.97 & 68.48 \\
3 & 7 & 21.84 & 1.13 & 9.46 & 67.57 \\
4 & 7 & 21.41 & 1.13 & 8.95 & 68.51 \\
5 & 7 & 21.40 & 1.19 & 8.92 & 68.49 \\
6 & 9 & 21.63 & 1.10 & 9.21 & 68.06 \\
7 & 7 & 21.34 & 1.15 & 8.92 & 68.59 \\
8 & 4 & 21.02 & 1.06 & 8.50 & 69.42 \\
Determined & & 21.44 & 1.13 & 8.98 & 68.45 \\
Calculated & & 21.06 & 1.16 & 8.53 & 69.25 \\
\hline
\end{tabular}

purity) were used as precursors in the synthesis by the solgel method. To measured quantities of $\mathrm{Eu}_{2} \mathrm{O}_{3}$ and $\mathrm{Na}_{2} \mathrm{CO}_{3}$ in $100 \mathrm{~mL}$ beakers, the concentrated nitric acid and distilled water were added drop by drop. Then $12 \mathrm{~mL}$ of ethyl alcohol and a precalculated volume of TEOS were added to each beaker to prevent hydrolysis. The solution was left for 12 hours and then evaporated until the formation of solid residue at $80^{\circ} \mathrm{C}$. This residue was transferred into alumina crucibles and calcined at temperatures ranging from $550^{\circ} \mathrm{C}$ to $1100^{\circ} \mathrm{C}$ as follows: $550^{\circ} \mathrm{C}$ for $6 \mathrm{~h}, 700^{\circ} \mathrm{C}$ for $15 \mathrm{~h}, 800^{\circ} \mathrm{C}$ for $20 \mathrm{~h}, 900^{\circ} \mathrm{C}$ for $43 \mathrm{~h}, 1000^{\circ} \mathrm{C}$ for $55 \mathrm{~h}$, and $1100^{\circ} \mathrm{C}$ for $30 \mathrm{~h}$. The density of the synthesized ceramics was about $60 \%$ of the theoretical value, due to the low sintering temperature $\left(1100^{\circ} \mathrm{C}\right)$ compared to the sintering temperature of apatite-like rare earth silicates containing no alkali metals $\left(1600-1750^{\circ} \mathrm{C}\right)$ [3]. Pellets were pressed from the powder, calcined at $900^{\circ} \mathrm{C}$, and sintered at $1100^{\circ} \mathrm{C}$ for 30 hours.

A $5 \%$ solution of polyvinyl alcohol was used as a binder for the production of ceramic pellets. The pressed pellets were dried at temperatures of $75-120^{\circ} \mathrm{C}$ to evaporate the alcohol, calcined for 3 hours at $500^{\circ} \mathrm{C}$, and sintered at $1100^{\circ} \mathrm{C}$ for 30 hours. The sintering temperature was not raised above $1100^{\circ} \mathrm{C}$ to avoid the possibility of sodium oxide sublimation [11]. Calcination was carried out until a consistent phase composition was attained. Preparation of the pellets for the measurements of electrical properties included polishing, washing with alcohol, and then annealing them in a muffle furnace after the deposition of the silver paste. The annealing was carried out at the following temperature conditions: rapid heating to $200^{\circ} \mathrm{C}$, then annealing from $200^{\circ} \mathrm{C}$ to $370^{\circ} \mathrm{C}$ at a heating rate of $3-3.5^{\circ} \mathrm{C} / \mathrm{min}$; from $370^{\circ} \mathrm{C}$ to $510^{\circ} \mathrm{C}$ at a rate of $4^{\circ} / \mathrm{min}$, and from $510^{\circ} \mathrm{C}$ to $850^{\circ} \mathrm{C}$ at a rate of $5^{\circ} \mathrm{C} / \mathrm{min}$ with the maximum temperature held for 10-15 minutes.

The electric conductivity measurements were carried out using a complex impedance meter (RLC E7-15 and E7-12) at a frequency of $1000 \mathrm{~Hz}$ while increasing the temperature from 320 to $750^{\circ} \mathrm{C}$ at $10^{\circ} \mathrm{C}$ increments in an electric resistance furnace with a chromel-alumel thermocouple.

Powder diffraction analysis was performed on X-ray diffractometers DRON-3 (Russia) using $\mathrm{CuK}_{\alpha}$ radiation and a

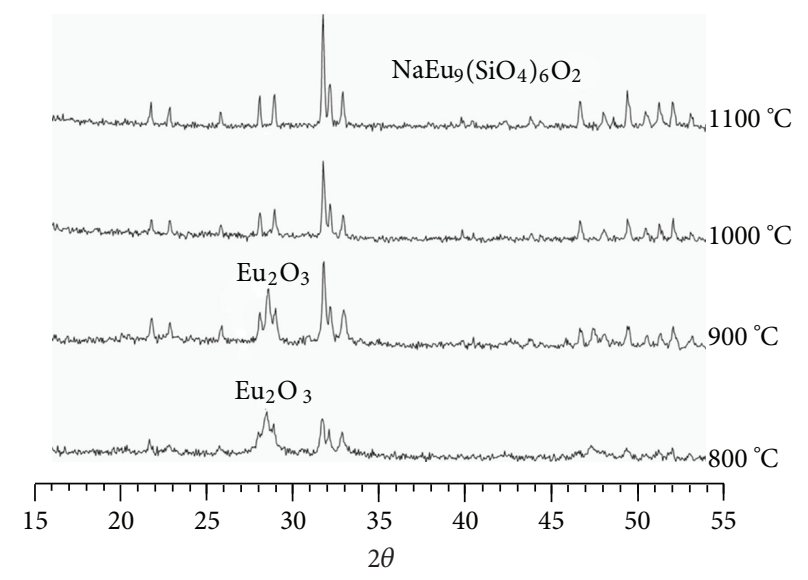

Figure 1: X-ray diffraction spectra for $\mathrm{NaEu}_{9}\left(\mathrm{SiO}_{4}\right)_{6} \mathrm{O}_{2}$ samples after calcination at $800,900,1000$, and $1100^{\circ} \mathrm{C}$.

Ni filter. The angular scan rate to determine the composition of the samples was $1-2^{\circ}$ per minute $(2 \theta)$. Rietveld refinement was then used to determine the crystalline structure by powder diffraction data. The angular range chosen for calculations was from 15 to $95^{\circ}(2 \theta)$. The angle increment and exposure times were $0.05^{\circ}$ and 3 seconds, respectively. The refinement was carried out using the FULLPROF.2k (version 3.40) software [17] with WinPLOTR graphic interface [18].

The semiquantitative elemental analysis has been performed using JEOL JSM-6490LV SEM with INCA Penta FETx3 (OXFORD Instruments) energy dispersion spectrometer. The precision was within $1 \%$. The micrographs and element distribution maps over the surface of the samples were also obtained using this instrument.

\section{Results and Discussion}

Powder diffraction has revealed that the apatite structures appear in the samples after calcination at $800^{\circ} \mathrm{C}$, but the phase composition is not yet uniform, as the lines corresponding to $\mathrm{Eu}_{2} \mathrm{O}_{3}$ phase still are quite visible. Figure 1 shows phase compositions for the samples sintered at temperatures ranging from 800 to $1100^{\circ} \mathrm{C}$.

The intensity of europium oxide lines during the synthesis of $\mathrm{NaEu}_{9}\left(\mathrm{SiO}_{4}\right)_{6} \mathrm{O}_{2}$ decreases considerably only after calcination at $1000^{\circ} \mathrm{C}$. The single phase $\mathrm{NaEu}_{9}\left(\mathrm{SiO}_{4}\right)_{6} \mathrm{O}_{2}$ has been obtained after calcination at $1100^{\circ} \mathrm{C}$.

The elemental composition in $\mathrm{NaEu}_{9}\left(\mathrm{SiO}_{4}\right)_{6} \mathrm{O}_{2}$, determined over 60 points (surface regions) on 8 thin sections, is in satisfactory consistency with the calculated data (see Table 1). This indicates that $\mathrm{Na}_{2} \mathrm{O}$ has not undergone sublimation during the apatite synthesis.

Electron microscopy reveals (see Figure 2) that the elements are distributed over the particle surface almost uniformly, which indicates the formation of a homogeneous sample. The residual nonuniformity is due to the surface pattern.

A fine powder was obtained from the synthesis; the size of aggregates was less than $10 \mu \mathrm{m}$, and the grains' size was about several hundred nanometers (Figure 3 ). 


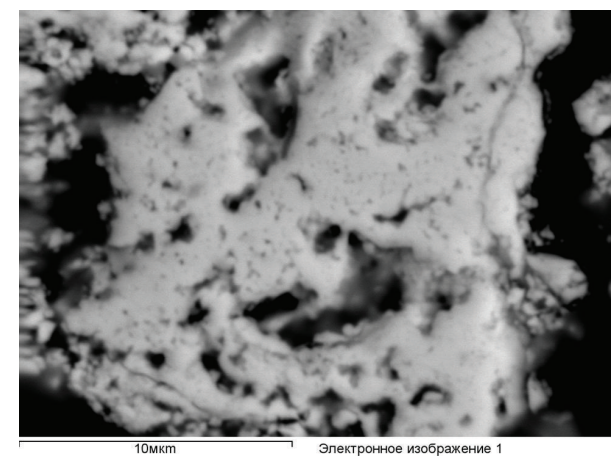

(a)

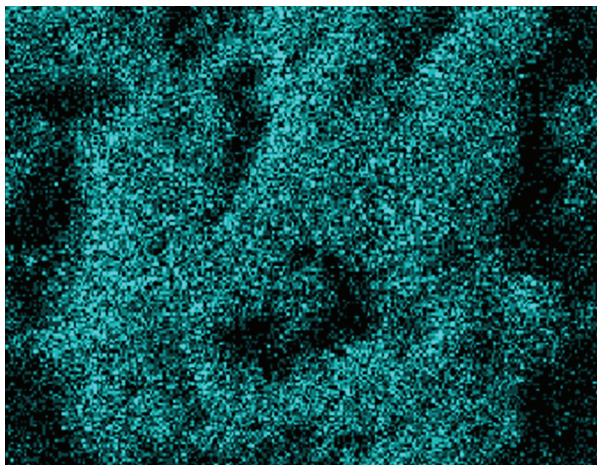

(b)

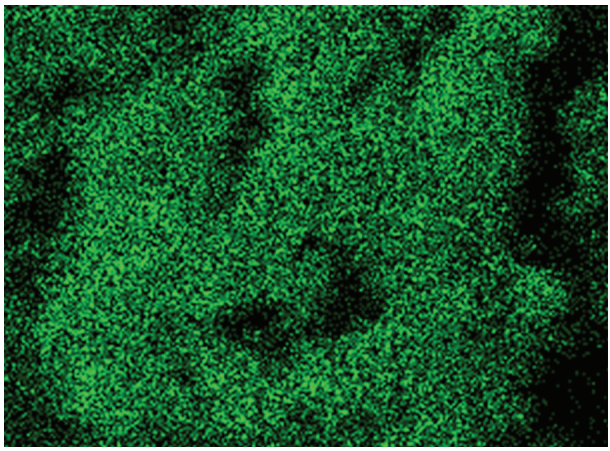

(d)

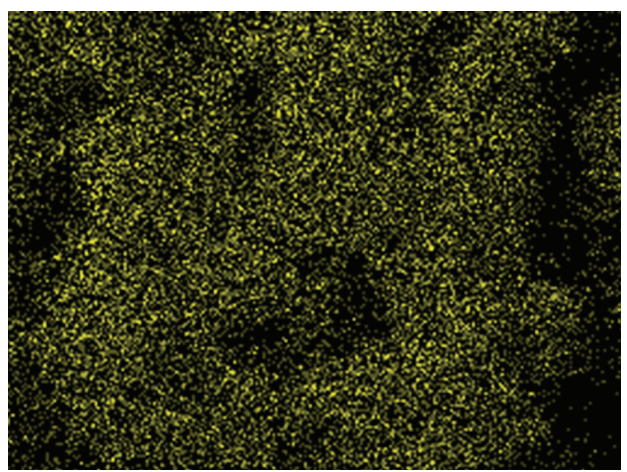

(c)

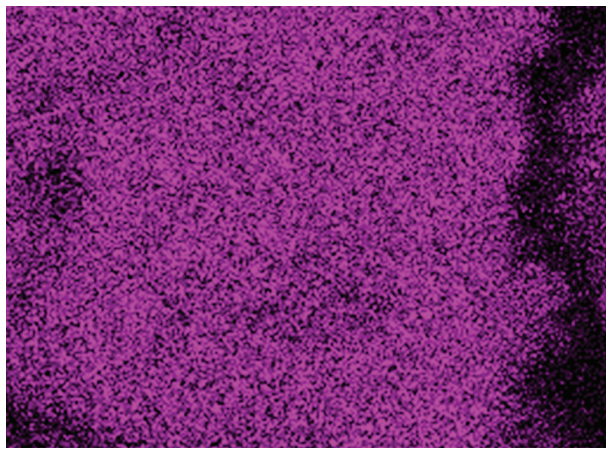

(e)

Figure 2: Distribution of elements in $\mathrm{NaEu}_{9}\left(\mathrm{SiO}_{4}\right)_{6} \mathrm{O}_{2}$ : (a) sample surface SEM scan, (b) O, (c) Na, (d) Si, (e) Eu.

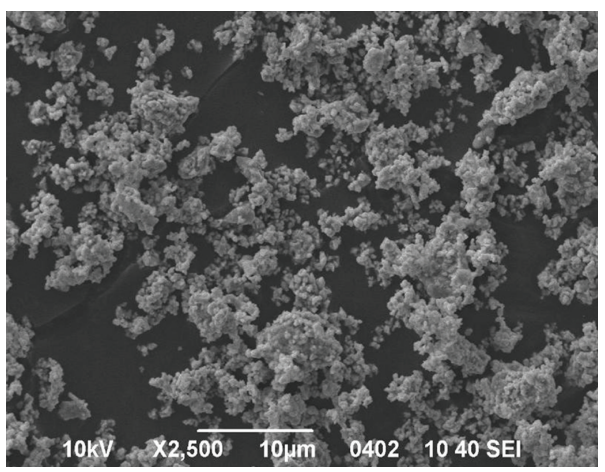

(a)

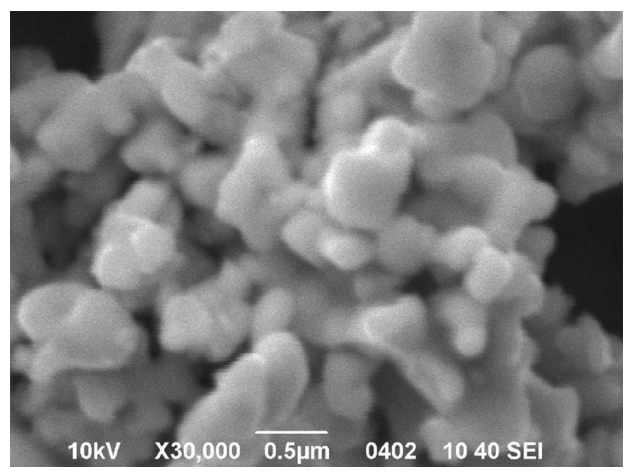

(b)

FIGURE 3: SEM scans of the sample surface with magnifications: (a) 2,500, (b) 30,000. 
TABLE 2: Coordinates, isotropic thermal parameters of atoms $B_{\text {iso }}$ and occupancies $G$ (space group P $6_{3} / \mathrm{m}, \mathbf{a}=9.4425(7), \mathbf{c}=6.9119(5), \AA$ ).

\begin{tabular}{|c|c|c|c|c|c|c|}
\hline Atom & Position & $x$ & $y$ & $Z$ & $B_{\text {iso }}, \AA^{2}$ & $G$ \\
\hline $\mathrm{Eu}(1)$ & $4 \mathrm{f}$ & $2 / 3$ & $1 / 3$ & 0.00217 & 0.512 & $0.745(8)$ \\
\hline $\mathrm{Na}(1)$ & $4 \mathrm{f}$ & $2 / 3$ & $1 / 3$ & 0.00217 & 0.512 & $0.255(8)$ \\
\hline $\mathrm{Eu}(2)$ & $6 \mathrm{~h}$ & $0.2320(5)$ & 0.9907 & $1 / 4$ & 0.198 & $1.003(5)$ \\
\hline $\mathrm{Na}(2)$ & $6 \mathrm{~h}$ & $0.2320(5)$ & 0.9907 & $1 / 4$ & 0.198 & $-0.003(5)$ \\
\hline $\mathrm{Si}$ & $6 \mathrm{~h}$ & $0.3998(6)$ & $0.374(2)$ & $1 / 4$ & 1.005 & 1 \\
\hline $\mathrm{O}(1)$ & $6 \mathrm{~h}$ & $0.3320(3)$ & $0.493(8)$ & $1 / 4$ & 1.693 & 1 \\
\hline $\mathrm{O}(2)$ & $6 \mathrm{~h}$ & 0.3320 & $0.473(4)$ & $1 / 4$ & 1.693 & 1 \\
\hline $\mathrm{O}(3)$ & $12 \mathrm{i}$ & 0 & $0.247(8)$ & $0.056(5)$ & 1.693 & 1 \\
\hline $\mathrm{O}(4)$ & $2 \mathrm{a}$ & 0 & 0 & $1 / 4$ & 1.693 & 1 \\
\hline
\end{tabular}

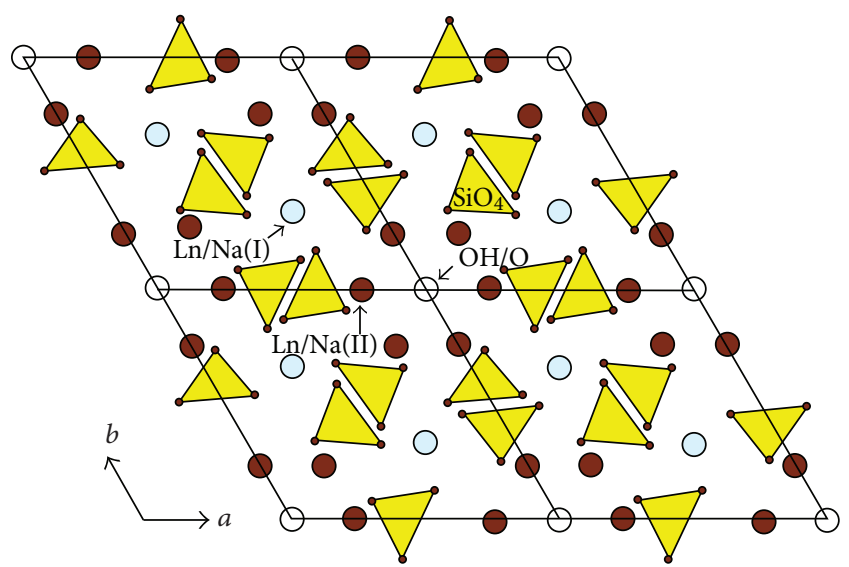

FIGURE 4: View of the refined crystal structure of the apatites [12].

Reitvelt refinement shows that the apatite structure (Figure 4) features two structurally nonequivalent positions in the cation sublattice, marked herein as $\operatorname{Ln}(1)$ and $\operatorname{Ln}(2)$ [12].

The $\operatorname{Ln}(1)$ position lies inside a ninefold coordination polyhedron. The coordination of the $\operatorname{Ln}(2)$ position is sevenfold, with six oxygen atoms of $\mathrm{SiO}_{4}$ tetrahedra and one $\mathrm{O}(4)$ placed in the channels of the structure (see Figure 4). It is also important to note that the cavity in the $\operatorname{Ln}(1)$ polyhedron is somewhat larger than that in the $\operatorname{Ln}(2)$ case. The $\mathrm{O}(4)$ atoms are placed at the centers of the equilateral triangles formed by the $\operatorname{Ln}(2)$ sublattice $[12,19]$.

The crystalline structure refinement was based on calcium hydroxyapatite as an initial data model [20]. The coordinates of atoms, isotropiC thermal parameters $B_{\text {iso }}$, and occupancies $G$ are given in Table 2 . The reliability factors are the following: $R_{\mathrm{P}}=0.0437 ; R_{\mathrm{F}}=0.0849 ; R_{\mathrm{wp}}=0.0635$; Bragg's $R$-factor $=0.0625 ; \chi^{2}=1.17$.

The above data show that the Eu atoms occupy all positions in sevenfold polyhedra (occupancy of $6 \mathrm{~h}$ position is 1.003). The ninefold sites are only partly occupied; Eu occupancy is only 0.745 for $4 \mathrm{f}$ position. The sodium atoms, due to their larger size compared to Eu atoms, occupy only some positions in larger ninefold polyhedra $(G=0.255$ for the $4 \mathrm{f}$ position). In contrast to the phosphate with apatite structure, the oxygen atoms $\mathrm{O}(4)$ are located at the
TABLE 3: Selected interatomic distances, $(\AA)$.

\begin{tabular}{lc}
\hline Atoms & Distances \\
\hline $\mathrm{Si}-\mathrm{O}(1)$ & $1.56(9)$ \\
$\mathrm{Si}-\mathrm{O}(2)$ & $1.69(7)$ \\
$\mathrm{Si}-\mathrm{O}(3) \times 2$ & $1.69(4)$ \\
$\langle\mathrm{Si}-\mathrm{O}\rangle$ & $1.66(3)$ \\
$\mathrm{Eu}, \mathrm{Na}(1)-\mathrm{O}(1) \times 3$ & $2.38(5)$ \\
$\mathrm{Eu}, \mathrm{Na}(1)-\mathrm{O}(2) \times 3$ & $2.40(6)$ \\
$\mathrm{Eu}, \mathrm{Na}(1)-\mathrm{O}(3) \times 3$ & $2.87(4)$ \\
$\langle\mathrm{Eu}, \mathrm{Na}(1)-\mathrm{O}(1,2,3)\rangle$ & $2.55(4)$ \\
$\mathrm{Eu}(2)-\mathrm{O}(1)$ & $2.77(7)$ \\
$\mathrm{Eu}(2)-\mathrm{O}(2)$ & $2.40(7)$ \\
$\mathrm{Eu}(2)-\mathrm{O}(3) \times 2$ & $2.51(3)$ \\
$\mathrm{Eu}(2)-\mathrm{O}(3) \times 2$ & $2.26(3)$ \\
$\langle\mathrm{Eu}(2)-\mathrm{O}(1,2,3)\rangle$ & $2.452(9)$ \\
$\mathrm{Eu}(2)-\mathrm{O}(4)$ & $2.275(7)$ \\
$\mathrm{Eu}(2)-\mathrm{Eu}(2)$ & $3.874(19)$ \\
\hline
\end{tabular}

centers of the triangles formed by $\operatorname{Eu}(2)$ atoms, apparently due to the larger radius of silicon atoms compared to phosphorus atoms. Similar results were reported earlier for $\mathrm{Eu}_{8.18} \mathrm{Na}_{1.08}\left(\mathrm{SiO}_{4}\right)_{6}(\mathrm{OH})_{1.62-2 \mathrm{y}} \mathrm{O}_{\mathrm{y}}$ [12], as well as $\mathrm{NaLa}_{9} \mathrm{Ge}_{6} \mathrm{O}_{26}$ [21], $\mathrm{NaPr}_{9} \mathrm{Ge}_{6} \mathrm{O}_{26}$, and $\mathrm{NaNd}_{9} \mathrm{Ge}_{6} \mathrm{O}_{26}$ [22].

The interatomic distances determined for the crystalline structure studied are given in Table 3.

Dimensions of the coordination polyhedron for the $\mathrm{Eu}(1)$ atoms are also larger than those for the $\mathrm{Eu}(2)$ one (mean Eu-O distances are 2.55(2) and $2.452 \AA$, resp.; see Table 3). This is for two reasons: first, different coordination numbers, 9 and 7; second, the preferential localization of larger $\mathrm{Na}^{+}$ compared to $\mathrm{Eu}^{3+}$ ions in the $\mathrm{Eu}(1)$ position. The small distance of $\mathrm{Eu}(2)-\mathrm{O}(4)$ is specific for oxygen atoms located in the structural channels, not related to silicate ions and interacting with three europium atoms.

To evaluate electrical conductivity, graphs of $\log \sigma$ against $1 / T$ were plotted to facilitate the data processing. The conductivity activation energy was calculated for different temperature ranges using the slopes of quasi-linear portions of the curve (see Figure 5). The lower temperature range was $300-440^{\circ} \mathrm{C}$, while the higher one was $450-750^{\circ} \mathrm{C}$. 
TABLE 4: DC and AC conductivity and activation energy for the samples.

\begin{tabular}{lcccr}
\hline Composition & $\begin{array}{c}\sigma\left(500^{\circ} \mathrm{C}\right), \\
\mathrm{mScm}^{-1}\end{array}$ & $\begin{array}{c}\sigma\left(600^{\circ} \mathrm{C}\right), \\
\mathrm{mScm}^{-1}\end{array}$ & $\begin{array}{c}\sigma\left(700^{\circ} \mathrm{C}\right), \\
\mathrm{mScm}^{-1}\end{array}$ & $E_{A}, \mathrm{eV}$ \\
\hline $\mathrm{NaEu}_{9}\left(\mathrm{SiO}_{4}\right)_{6} \mathrm{O}_{2}$ (direct current) & 0.547 & 1.887 & 3.120 & 0.62 \\
$\mathrm{NaEu}_{9}\left(\mathrm{SiO}_{4}\right)_{6} \mathrm{O}_{2}(1000 \mathrm{~Hz})$ & 1.257 & 2.681 & 4.059 & 0.77 \\
$\mathrm{La}_{9.33} \mathrm{Si}_{6} \mathrm{O}_{26}[3]$ & 0.023 & - & 0.26 & 0.84 \\
$\mathrm{La}_{9} \mathrm{Mg}_{0.5} \mathrm{Si}_{6} \mathrm{O}_{26}[3]$ & 0.021 & - & - & 0.98 \\
$\mathrm{La}_{8.67} \mathrm{SrSi}_{6} \mathrm{O}_{26}[3]$ & 0.083 & - & - & 0.87 \\
$\mathrm{La}_{8.67} \mathrm{CaSi}_{6} \mathrm{O}_{26}[3]$ & 0.058 & - & - & 0.87 \\
\hline
\end{tabular}

TABLE 5: Selected interatomic distances, $(\AA)$.

\begin{tabular}{lccccc}
\hline Composition & $\mathrm{Si}-\mathrm{O}(1)$ & $\mathrm{Si}-\mathrm{O}(2)$ & Si-O(3) & Max. difference & Reference \\
\hline $\mathrm{NaEu}_{9}\left(\mathrm{SiO}_{4}\right)_{6} \mathrm{O}_{2}$ & 1.56 & 1.69 & $1.69 \times 2$ & 0.13 & Current work \\
$\mathrm{Eu}_{8.18} \mathrm{Na}_{1.08}\left(\mathrm{SiO}_{4}\right)_{6}(\mathrm{OH})_{1.62-2 \mathrm{y}} \mathrm{O}_{\mathrm{y}}$ & 1.668 & 1.567 & $1.616 \times 2$ & 0.101 & {$[12]$} \\
$\mathrm{La}_{9.33}\left(\mathrm{SiO}_{4}\right)_{6} \mathrm{O}_{2}$ & 1.618 & 1.630 & $1.623 \times 2$ & 0.012 & {$[13]$} \\
$\mathrm{La}_{9.67} \mathrm{Si}_{6} \mathrm{O}_{26.5}$ & 1.622 & 1.633 & $1.631 \times 2$ & 0.011 & {$[14]$} \\
$\mathrm{La}_{9.55}\left(\mathrm{SiO}_{4}\right)_{6} \mathrm{O}_{2.32}$ & 1.621 & 1.631 & $1.617 \times 2$ & 0.014 & {$[15]$} \\
$\mathrm{La}_{9.33}\left(\mathrm{SiO}_{4}\right)_{6} \mathrm{O}_{2}$ & 1.65 & 1.60 & $1.63 \times 2$ & 0.05 & {$[16]$} \\
$\mathrm{Na}_{9.33}\left(\mathrm{SiO}_{4}\right)_{6} \mathrm{O}_{2}$ & 1.63 & 1.64 & $1.61 \times 2$ & 0.03 & {$[16]$} \\
\hline
\end{tabular}

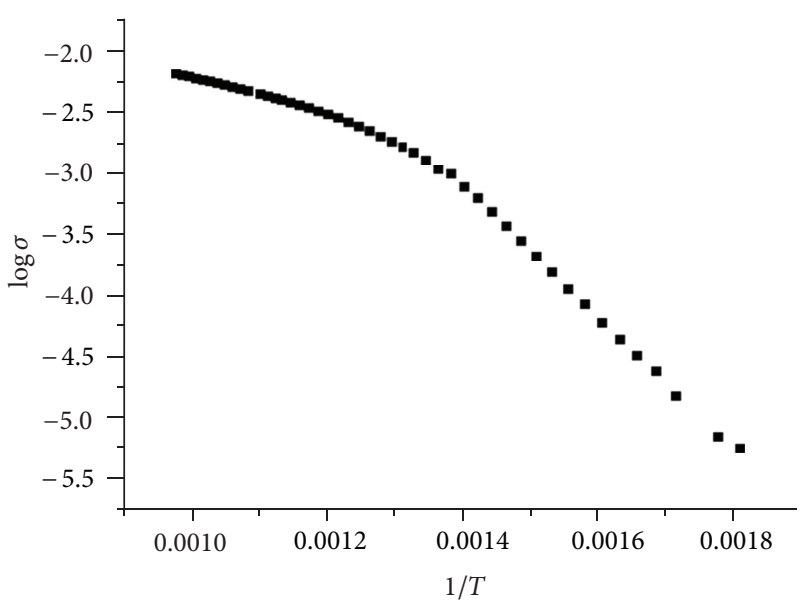

FIGURE 5: Logarithm of conductivity, $\sigma\left(\mathrm{mScm}^{-1}\right)$ as a function of $1 / T\left(\mathrm{~K}^{-1}\right)$ for $\mathrm{NaEu}_{9}\left(\mathrm{SiO}_{4}\right)_{6} \mathrm{O}_{2}$.

The inflection point on the Arrhenius plot is due to a transition from extrinsic to intrinsic conductivity as the temperature increases. The values of DC and AC electric conductivity as well as activation energy were measured for this compound and given in Table 4 .

As can be seen from the data, the conductivity values measured at the alternating current are higher than the values measured at the direct current, because both active and reactive components of the conductivity are measured at the alternating current (capacitive and/or inductive), and only the active component is measured at the direct current.

$\mathrm{NaEu}_{9}\left(\mathrm{SiO}_{4}\right)_{6} \mathrm{O}_{2}$ has greater electrical conductivity, and in most cases slightly lower activation energy compared to lanthanum silicates $\mathrm{La}_{9.33} \mathrm{Si}_{6} \mathrm{O}_{26}$ as well as some silicates of lanthanum doped with magnesium and alkaline earth metals $\mathrm{La}_{9} \mathrm{M}_{\mathrm{g} 0.5} \mathrm{Si}_{6} \mathrm{O}_{26}, \mathrm{La}_{8.67} \mathrm{SrSi}_{6} \mathrm{O}_{26}$, and $\mathrm{La}_{8.67} \mathrm{CaSi}_{6} \mathrm{O}_{26}$ [3]. An increase in electrical conductivity in compounds containing excess oxygen atoms, such as $\mathrm{La}_{10} \mathrm{Si}_{6} \mathrm{O}_{27}$, was established previously [3]. A greater electrical conductivity of $\mathrm{NaEu}_{9}\left(\mathrm{SiO}_{4}\right)_{6} \mathrm{O}_{2}$ can be explained by local distortion of the crystal structure since it does not have excess of oxygen. The alkali metal replacing europium has a much smaller charge and larger size. Some oxygen atoms of each $\mathrm{SiO}_{4}$ tetrahedron surround both $\mathrm{Eu}(1)$ and $\mathrm{Eu}(2)$. This leads to a weaker electrostatic interaction of oxygen with the $\mathrm{Eu}(1)$ and a stronger electrostatic interaction with $\mathrm{Eu}(2)$, respectively, and as a result distorts the geometry of $\mathrm{SiO}_{4}$, which is confirmed by the results presented in Table 5 .

As shown in Table 5, the maximum $\mathrm{Si}-\mathrm{O}$ distance differences in the $\mathrm{SiO}_{4}$ tetrahedra containing no alkali metals are in the range of $0.01-0.05 \AA$, while they are significantly larger $(0.10-0.13 \AA)$ in $\mathrm{NaEu}_{9}\left(\mathrm{SiO}_{4}\right)_{6} \mathrm{O}_{2}$ and double silicates containing sodium [12]. This can affect the mobility of the oxygen ions in the structure, and thus the electrical conductivity.

\section{Conclusions}

The sol-gel method has been used to obtain a sodium europium silicate with apatite structure, $\mathrm{NaEu}_{9}\left(\mathrm{SiO}_{4}\right)_{6} \mathrm{O}_{2}$. Elemental composition determined by X-ray energy dispersion spectra is in good agreement with computational data (analysis error is under 1\%). The crystalline structure of $\mathrm{NaEu}_{9}\left(\mathrm{SiO}_{4}\right)_{6} \mathrm{O}_{2}$ has been refined using the Rietveld method. It has been found that Eu atoms occupy all $6 \mathrm{~h}$ positions in sevenfold polyhedra, while the ninefold ones (4f position) are 
occupied by Eu and $\mathrm{Na}$ atoms. The electric conductivity has been measured at the temperature range of $320-750^{\circ} \mathrm{C}$ and found to be the same or higher than that for some lanthanum silicates without sodium.

\section{Acknowledgments}

Authors are grateful to D. N. Afanassiev for valuable discussion and help and Dr. Steven Losh for editorial help.

\section{References}

[1] D. Grossin, S. Rollin-Martinet, C. Estournès et al., "Biomimetic apatite sintered at very low temperature by spark plasma sintering: physico-chemistry and microstructure aspects," Acta Biomaterialia, vol. 6, no. 2, pp. 577-585, 2010.

[2] S. Kale, S. Kahandal, S. Disale, and R. Jayaram, "Conventional and microwave-assisted multicomponent reaction of alkyne, halide and sodium azide catalyzed by copper apatite as heterogeneous base and catalyst in wate," Current Chemistry Letters, vol. 1, pp. 69-80, 2012.

[3] H. Yoshioka, Y. Nojiri, and S. Tanase, "Ionic conductivity and fuel cell properties of apatite-type lanthanum silicates doped with $\mathrm{Mg}$ and containing excess oxide ions," Solid State Ionics, vol. 179, no. 38, pp. 2165-2169, 2008.

[4] J. Zhang, H. Liang, R. Yu, H. Yuan, and Q. Su, "Luminescence of $\mathrm{Ce}^{3+}$-activated chalcogenide apatites $\mathrm{Ca}_{10}\left(\mathrm{PO}_{4}\right)_{6} \mathrm{Y}(\mathrm{Y}=\mathrm{S}, \mathrm{Se})$," Materials Chemistry and Physics, vol. 114, no. 1, pp. 242-246, 2009.

[5] M. Higuchi, H. Katase, K. Kodaria, and S. Nakayama, "Ionic conductivities of apatite type $\mathrm{NdX}\left(\mathrm{SiO}_{4}\right)_{6} \mathrm{O}_{1.5 X-12}(\mathrm{X}=9.20$ and 9.33) single crystals," Journal of Materials Science Letters, vol. 19, no. 2, pp. 91-93, 2000.

[6] H. Arikawa, H. Nishiguchi, T. Ishihara, and Y. Takita, "Oxide ion conductivity in Sr-doped $\mathrm{La}_{10} \mathrm{Ge}_{6} \mathrm{O}_{27}$ apatite oxide," Solid State Ionics, vol. 136-137, pp. 31-37, 2000.

[7] T. Kharlamova, S. Pavlova, V. Sadykov et al., "Low-temperature synthesis methods of doped apatite-type lanthanum silicates," Journal of Chemical Engineering of Japan, vol. 40, no. 13, pp. 1187-1191, 2007.

[8] I. Rosales, E. Orozco, L. Bucio, M. E. Fuentes, and L. Fuentes, "Structural characterization of $\mathrm{Na}_{0.96} \mathrm{Ho}_{9.04}\left(\mathrm{SiO}_{4}\right)_{6} \mathrm{Cl}_{0.02} \mathrm{O}_{1.98}$ apatite prepared by mechanical milling," Journal of Chemical Crystallography, vol. 40, no. 4, pp. 323-327, 2010.

[9] S. Tao and J. T. S. Irvine, "Preparation and characterisation of apatite-type lanthanum silicates by sol-gel processes," Materials Research Bulletin, vol. 36, no. 7, pp. 1245-1258, 2001.

[10] J. Ito, "Silicate apatites and oxyapatites," American Mineralogist, vol. 53, no. 5-6, pp. 890-907, 1968.

[11] J. Felsche, "Rare earth silicates with the apatite structure," Journal of Solid State Chemistry, vol. 5, no. 2, pp. 266-275, 1972.

[12] S. Ferdov, R. A. Sa'Ferreira, and Z. Lin, "Hydrothermal synthesis, structural investigation, photoluminescence features, and emission quantum yield of Eu and $\mathrm{Eu}-\mathrm{Gd}$ silicates with apatitetype structure," Chemistry of Materials, vol. 18, no. 25, pp. 5958-5964, 2006.

[13] L. León-Reina, E. R. Losilla, M. Martínez-Lara et al., "Interstitial oxygen in oxygen-stoichiometric apatites," Journal of Materials Chemistry, vol. 15, no. 25, pp. 2489-2498, 2005.

[14] S. Guillot, Étude des paramètres principaux gouvernant les propriétés de conduction dans les apatites, électrolytes pour piles
SOFC [Thèse de doctorat de Lille 1], Molécules et Matière Condensée, 2009.

[15] A. Jones, P. R. Slater, and M. Saiful Islam, "Local defect structures and ion transport mechanisms in the oxygen-excess apatite $\mathrm{La}_{9.67}\left(\mathrm{SiO}_{4}\right)_{6} \mathrm{O}_{2.5}$, Chemistry of Materials, vol. 20, no. 15, pp. 5055-5060, 2008.

[16] A. Norlund Christensen, R. G. Hazell, and A. W. Hewatt, "Synthesis, crystal growth and structure investigations of rareearth disilicates and rare-earth oxyapatites," Acta Chemica Scandinavica, vol. 51, pp. 37-43, 1997.

[17] C. J. Rodriguez, Program FullProf. 2k, version 3. 40.LLB JRC (unpublished), November 2005.

[18] T. Roisnel and J. Rodríguez-Carvajal, "WinPLOTR: a windows tool for powder diffraction pattern analysis," Materials Science Forum, vol. 378-381, no. I, pp. 118-123, 2001.

[19] W. Bragg and G. Klaringbull, Crystal Structure of Minerals, vol. 390, Mir, Moscow, Russia, 1967.

[20] R. M. Wilson, J. C. Elliot, and S. E. P. Dowker, "Rietveld refinement of the crystallographic structure of human dental enamel apatites," American Mineralogist, vol. 84, pp. 1406-1414, 1999.

[21] M. Takahashi, K. Uematsu, Z. G. Ye, and M. Sato, "Single-crystal growth and structure determination of a new oxide apatite, $\mathrm{NaLa}_{9}\left(\mathrm{GeO}_{4}\right)_{6} \mathrm{O}_{2}$," Journal of Solid State Chemistry, vol. 139, no. 2, pp. 304-309, 1998.

[22] M. Emirdag-Eanes, W. T. Pennington, and J. W. Kolis, "Synthesis, structural characterization, and magnetic properties of $\mathrm{NaRE}_{9}\left(\mathrm{GeO}_{4}\right)_{6} \mathrm{O}_{2}(\mathrm{RE}=\mathrm{Nd}, \mathrm{Pr})$," Journal of Alloys and Compounds, vol. 366, no. 1-2, pp. 76-80, 2004. 

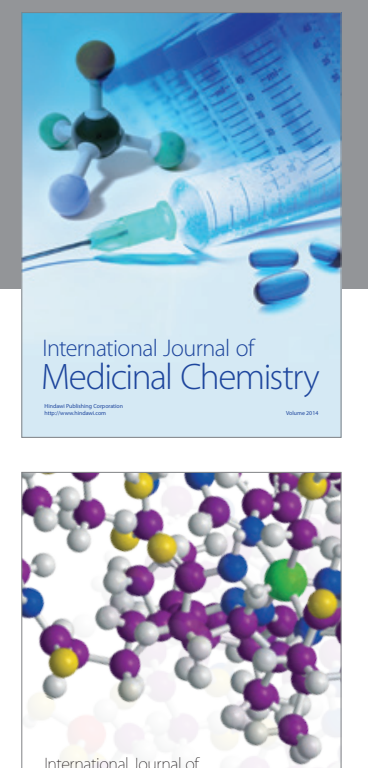

\section{Carbohydrate} Chemistry

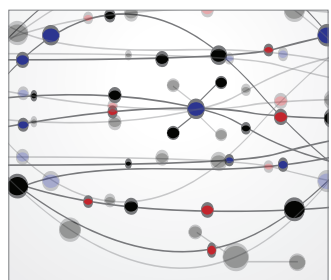

The Scientific World Journal
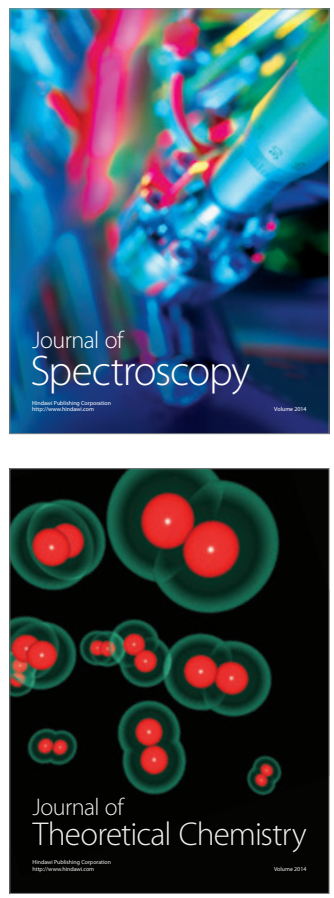
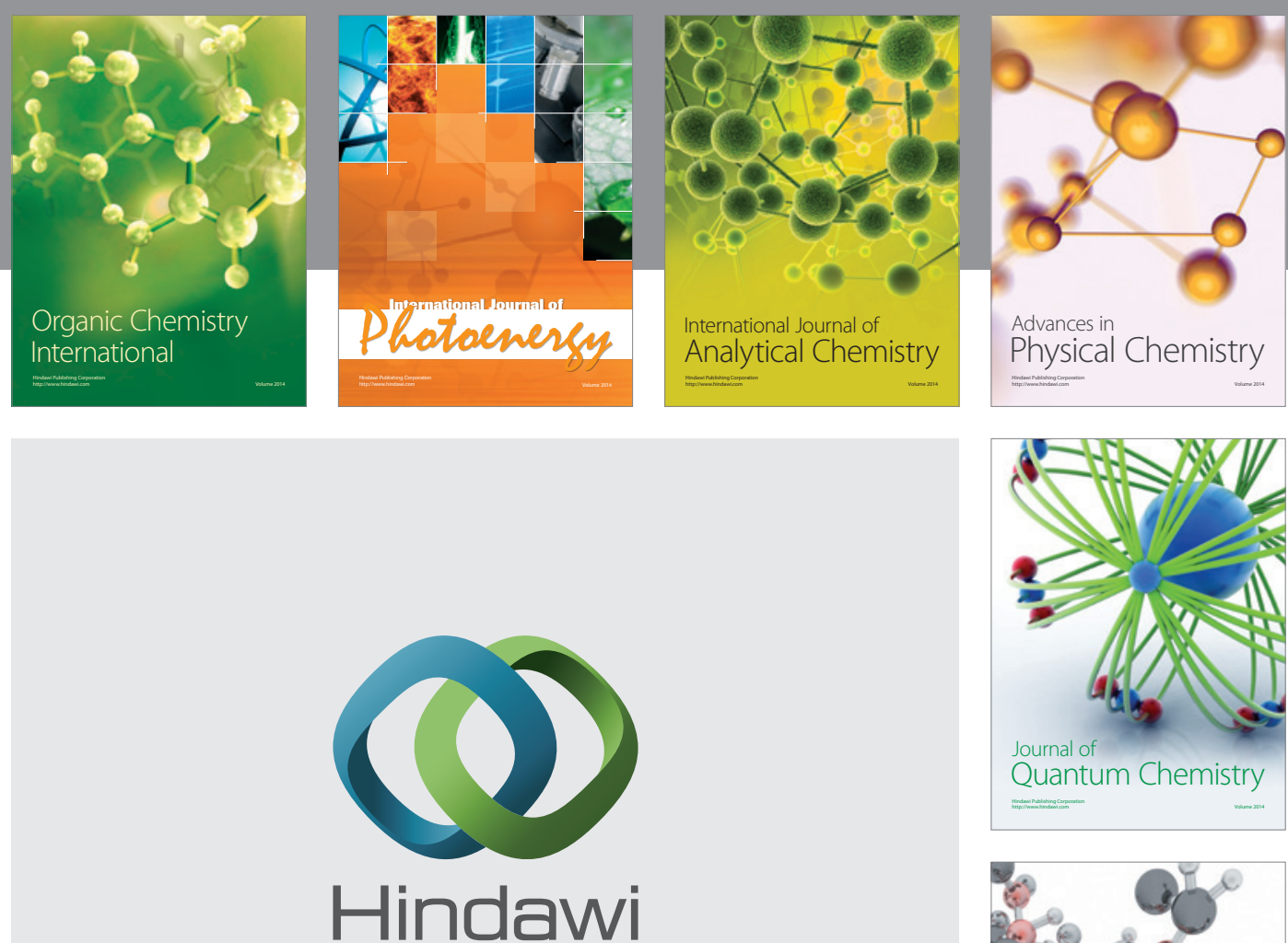

Submit your manuscripts at

http://www.hindawi.com

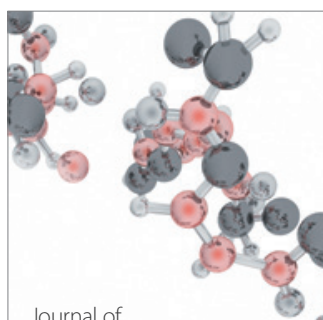

Analytical Methods

in Chemistry

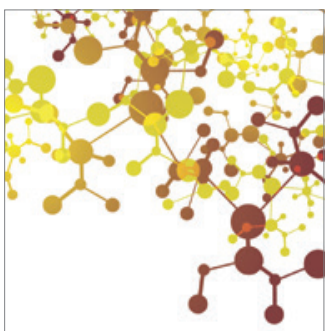

Journal of

Applied Chemistry

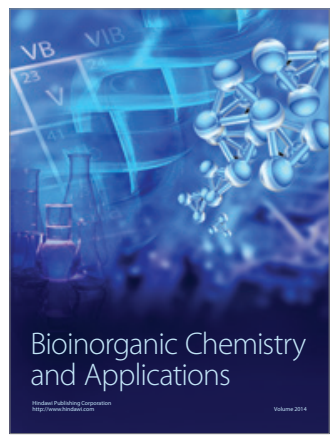

Inorganic Chemistry
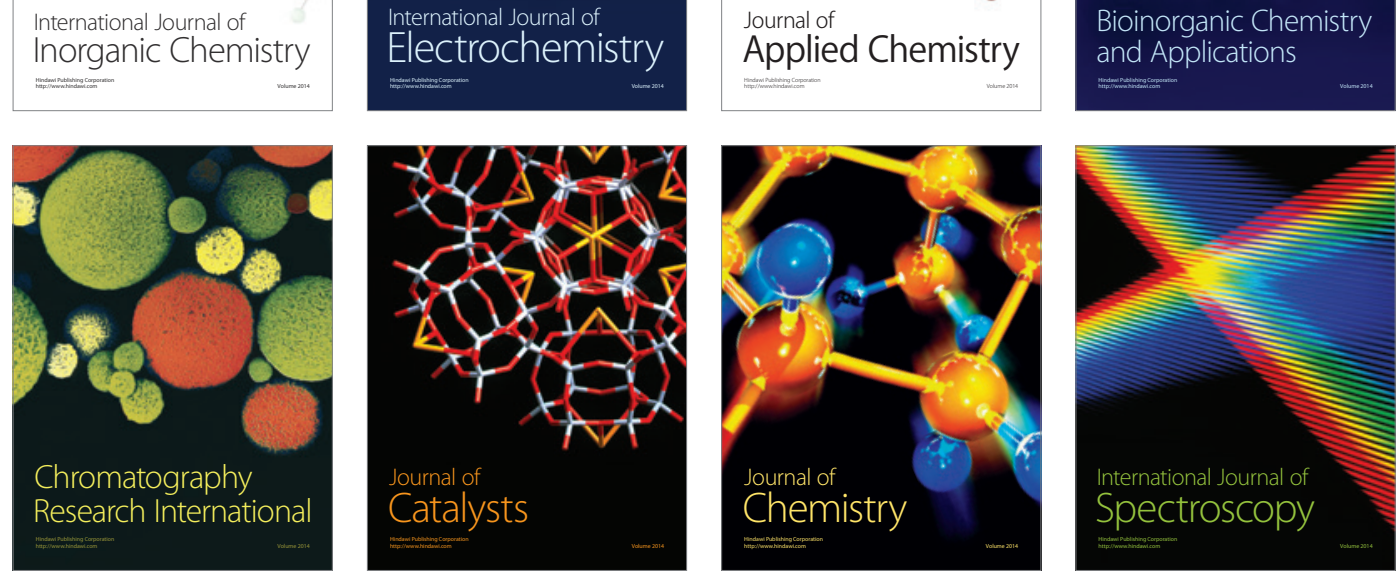